Validation of a coping scale in an African context

Carelyn van der Walt 


\title{
Validation of a coping scale in an African context
}

\author{
Carelyn van der Walt \\ Hons B.A. (Psychology)
}

Mini-dissertation (article format) submitted in partial fulfilment of the requirements for the degree Magister Artium (Clinical Psychology) at the North-West University, Potchefstroom Campus

Supervisor: Dr. J.C. Potgieter

Co-supervisor: Prof. M.P. Wissing

Co-supervisor: Dr. Q. M. Temane

Potchefstroom

November 2007 


\section{TABLE OF CONTENTS}

1. Acknowledgements 5

2. Solemn declaration 6

3. Summary

$\begin{array}{ll}\text { 4. Opsomming } & 10\end{array}$

5. Preface 13

5.1. Article format 13

5.2. Intended Journal 13

5.3. Letter of consent 14

6. Manuscript: Validation of a coping scale in an African context 15

6.1. Instructions to Authors 16

$\begin{array}{ll}\text { 6.2. Manuscript title, authors and addresses } & 18\end{array}$

$\begin{array}{ll}\text { Abstract } & 20\end{array}$

Introduction and background $\quad 21$

Method: $\quad 24$

Design 24

Participants 24

Measures 25

Procedure 27

Data analysis $\quad 29$

Ethical considerations $\quad 29$

Results: $\quad 29$

Descriptive statistics and reliability indices

for the N-COPE 29

Factor analysis $\quad 30$

Criterion-related validity of the N-COPE 33

Discussion: 33

Shortcomings of the current study and

suggestions for future research 39

Conclusion $\quad 40$

Acknowledgements $\quad 42$ 
References

Addend

Table 1

48

Table 2

49

Table 3

50

N-COPE: English version

51

Correspondence with the authors

54 


\section{ACKNOWLEDGEMENTS}

- My Heavenly Father for providing me with the opportunity, guidance and strength to complete the research.

- Special thanks to my parents and the rest my family for their support, caring and encouragement throughout this year.

- Danie for his friendship, support and prayers.

- My supervisor, Dr. J.C. Potgieter for his assistance, guidance, insight and encouragement.

- My co-supervisors, Prof. M.P. Wissing and Dr. Q.M. Temane for their assistance, guidance and insight.

- The co-ordinator of the PURE-SA project, Prof. A. Kruger, as well as the coordinators of the international PURE project.

- Prof. M.P. Wissing as co-ordinator of the FORT2 project.

- The translators who assisted with the translation of the N-COPE and other measures used in the study.

- Prof. F.S. Steyn for his assistance with the statistical analyses.

- Sinette, Wilmien, Jovika and Sandra for their assistance and support as part of the research team.

- The language editor for editing the manuscript.

- The NRF for providing the necessary financial means to complete this research.

- All the research participants, without whom this study would not have been possible. 


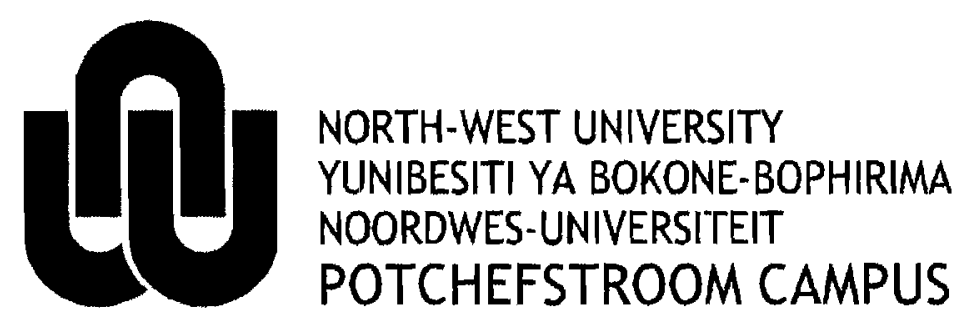

\section{Academic Administration \\ SOLEMN DECLARATION}

\section{Solemn declaration by student}

I dissertation/dissertation/thesis entitled, declare herewith that the mini-

which I herewith submit to the North-West University as completion/partial completion of the requirements set for the degree, is my own work, has been text edited and has not already been submitted to any other university. I understand and accept that the copies that are submitted for examination are the property of the University.

Signature of student Universitynumber

Signed at this day of $20 \ldots$.

Declared before me on this day of $20 \ldots$. Commissioner of Oaths:

\section{Declaration by supervisor/promotor}

The undersigned declares:

1.1 that the student attended an approved module of study for the relevant qualification and that the work for the course has been completed or that work approved by the Senate has been done;

1.2 the student is hereby granted permission to submit his/her mini-dissertation/dissertation or thesis;

1.3 that registration/change of the title has been approved;

1.4 that the appointment/change of examiners has been finalised and

1.5 that all the procedures have been followed according to the Manual for Postgraduate studies.

Signature of

Supervisor: Date: 


\section{SUMMARY}

\section{Validation of a coping scale in an African context}

Key words: African context; coping; psychological well-being; psychometric properties; validation; ACSI; N-COPE; S-COPE.

This research was aimed at compiling and validating a multi-dimensional coping measure that takes African-centred coping behaviour into consideration. A review of relevant literature revealed numerous previous studies on coping, the development of various coping models and studies on the relationship between coping and other variables. Only a few studies on the possible intercultural differences in coping behaviour, and more specifically studies focusing on the possibility of emic coping patterns in an African context, could however be found. Furthermore, studies that were done in an African context implemented scales that were developed from a Western perspective on coping, not incorporating coping strategies found to be more prevalent in more collectivistic Asian and African American populations. The need for a multi-dimensional coping measure for the South African context that was developed with both the Western and African conceptual frameworks in mind became apparent. Therefore, the aim of this study is to validate a multi-dimensional measure of coping, using an African sample of Setswana-speaking South Africans.

The S-COPE (Stapelberg, 1999) and the ACSI (Utsey, Adam \& Bolden, 2000) was administered to a sample of 274 Setswana-speaking participants in the pilot study. The S-COPE served as a measure representative of a traditional dichotomous view of clusters of coping strategies as either Problem- or Emotion-focused. The S-COPE entails an adapted version of the COPE (Carver et al., 1989) that has been translated into Setswana. The ACSI (Utsey, Adams \& Bolden, 2000) was administered to the same group of participants as it represents an African-centred view of coping that incorporates strategies developed from this perspective. It involves four sub-scales, named Cognitive/emotional debriefing; Spiritual-centred; Collective and Ritualcentred coping. The ACSI and the S-COPE were selected for this study on grounds of 
applicability, previously indicated reliability and the distinct conceptual frameworks from which they were developed.

Based on the results from the pilot study, selected items from the ACSI and the SCOPE were combined into a single measure, called the N-COPE. Item selection was based on yielded standard deviations, correlations and final communality estimates of individual items. For purposes of validation, the N-COPE, together with a number of measures of psychological well-being were administered to another group of participants from the same community $(N=1050)$ in the main study. Reliability indices were determined for the N-COPE, yielding a Cronbach alpha of .74 for the total scale, indicating that the N-COPE can be viewed as a measure of coping behaviour. No conclusions concerning the reliability of N-COPE sub-scales can be drawn from this value. As only selected items from both the ACSI and the S-COPE were used in the compilation of the N-COPE, complete sub-scales from these original measures are not represented in the N-COPE. Therefore, confirmatory factor analysis was not applicable and an exploratory factor analysis was conducted. Results from the exploratory factor analysis showed the following six-factor model of the 35-item NCOPE: (1) Active problem solving with help from others (APO) ( $\alpha=.74)$; (2) Spiritual and cultural rituals for solving the problem (SCR) $(\alpha=.73)$; (3) Participation in religious activities (PRA) $(\alpha=.35)$; (4) Acceptance (ACC) $(\alpha=.55)$; (5) Denial (DEN) $(\alpha=.42)$; and (6) Escape in social activities (ESA) $(\alpha=.44)$. Cronbach alpha reliabilities for the subscales varied from good to unsatisfactory $(.73-.35)$. Criterionrelated validity of the N-COPE was determined by comparing it with other measures of psychological well-being.

The extracted factors in the current study were largely similar to factors from relevant African American and Asian studies on coping, but also showed a number of apparent differences. Coping strategies in this African context proved to be biased towards secondary control efforts (changing one's individual experience of a situation, in stead of attempting to change existing realities) as means of coping, rather than a traditional Western perspective that views secondary control efforts as ineffective and detrimental to well-being. Secondly, distinct differences in the configuration of coping factors in this group of Africans were illustrated through their greater reliance 
on the employment of relational support, religion, and spirituality as successful coping strategies.

Limitations of the study and suggestions for future research were discussed.

It is concluded that the N-COPE in its current form is not completely valid to be utilized in an African context, but the measure holds promising possibilities with further refinement. Results of extracted factors revealed a different configuration than those previously indicated for both the S-COPE and the ACSI. To determine whether this different configuration of factors can be indicative of an emic pattern of coping behaviour in this Setswana-speaking group of Africans, subsequent studies where the N-COPE is administered to other groups of participants in the South African context needs to be conducted. 


\section{OPSOMMING}

\section{Validering van ' $n$ coping-skaal in 'n Afrika-konteks}

Sleutelterme: Afrika-konteks; coping; psigologiese welstand; psigometriese eienskappe; validering; ACSI; N-COPE; S-COPE.

Die doel van hierdie studie was om ' $\mathrm{n}$ multi-dimensionele coping-skaal wat moontlike unieke Afrika-gesentreerde patrone van coping-gedrag in ag neem, saam te stel en die geldigheid daarvan in ' $n$ Afrika-konteks te bepaal. 'n Oorsig van relevante literatuur het aangetoon dat daar reeds verskeie studies oor coping onderneem is en dat dit gelei het tot die ontwikkeling van verskeie modelle van coping, asook die bestudering van die verhouding tussen coping en ander veranderlikes. Weinig studies oor die moontlike interkulturele verskille in coping-gedrag en meer spesifiek, slegs enkele studies wat op ' $n$ moontlike unieke coping-patrone in die Suid-Afrikaanse konteks fokus, kon gevind word. Verder is bevind dat studies wat wel in die Suid-Afrikaanse konteks onderneem is, steeds skale wat slegs vanuit ' $n$ Westerse perspektief tot coping-gedrag ontwikkel is, bevat en nie die meer kollektiwitiese coping-strategieë wat algemeen in die Asiese en Afrikaans-Amerikaanse kontekse voorkom insluit nie. Die behoefte aan ' $\mathrm{n}$ coping-skaal wat die moontlike unieke coping-patrone van Afrikane in ag neem en vanuit beide ' $n$ Westerse en ' $n$ Afrika konseptuele raamwerk ontwikkel is, het aan die lig gekom. Gevolglik was die doel van hierdie studie om die geldigheid van ' $\mathrm{n}$ multi-dimensionele coping-skaal in ' $\mathrm{n}$ Suid-Afrikaanse groep Setswana-sprekende Afrikane te bepaal.

Tydens die loodsstudie is die S-COPE (Stapelberg, 1999) en die ACSI (Utsey, Adams \& Bolden, 2000) op ' $n$ groep Setswana-sprekende deelnemers $(N=274)$ afgeneem. Die S-COPE is gebruik as voorbeeld van ' $n$ tradisioneel Westerse beskouing van groepe coping-strategieë, waar dit tweeledig as Probleem- of Emosie-gefokus gedefinieer word en behels ' $n$ Setswana vertaling en aanpassing van die COPE (Carver et al., 1989). Die ACSI is ook op dieselfde groep deelnemers afgeneem aangesien dit as voorbeeld dien van ' $n$ skaal wat strategieë insluit, wat vanuit die Afrika konseptuele raamwerk ontwikkel is. Die ACSI betrek vier faktore, naamlik: 
Kognitief-emosionele ontlading, Spiritueel-gefokusde, Kollektiewe en Ritueelgefokusde coping. Die S-COPE en die ACSI is op grond van toepaslikheid, goeie betroubaarheidindekse in vorige studies en die onderskeie konseptuele raamwerke waaruit hulle ontwikkel is, vir gebruik in hierdie studie geselekteer.

$\mathrm{Na}$ aanleiding van die resultate in die loodsstudie is items vanuit beide skale verkies en in een 35-item skaal, die N-COPE saamgevoeg. Item-seleksie is gebaseer op items se standard afwykings, korrelasies en kommunaliteite. Die N-COPE is met die doel om die geldigheid daarvan te bepaal in die hoofstudie tesame met ' $n$ aantal skale van psigologiese gesondheid op nog ' $n$ groep deelnemers vanuit dieselfde gemeenskap afgeneem $(N=1050)$. Die N-COPE het 'n Cronbach alpha van .74 vir die totaalskaal getoon wat slegs aandui dat die N-COPE wel coping-gedrag meet. Geen gevolgtrekking oor die betroubaarheid van subskale kan op grond van hierdie telling gemaak word nie. Aangesien slegs geselekteerde items in die N-COPE ingesluit is, word die subskale soos aanvanklik vir die ACSI en die S-COPE aangedui, nie in die N-COPE verteenwoordig nie. Dus was ' $n$ bevestigende faktorontleding nie geskik nie en is begin met ' $n$ eksploratiewe faktorontleding. Resultate verkry na die toepassing van ' $n$ eksploratiewe faktorontleding met die data, het ' $n$ ses-faktor struktuur vir die 35-item N-COPE aangedui. Die ses faktore is soos volg benoem: (1) Aktiewe probleemoplossing met hulp van ander (APO) ( $\alpha=.74)$; (2) Spirituele en kulturele rituele vir probleemoplossing (SCR) $(\alpha=.73)$; (3) Deelname aan godsdienstige aktiwiteite (PRA) ( $\alpha=.35$ ); (4) Aanvaarding (ACC) ( $\alpha=.55$ ); (5) Ontkenning (DEN) $(\alpha=.42)$; en (6) Ontsnapping deur sosiale aktiwiteite (ESA) $(\alpha=.44)$. Cronbach alpha betroubaarhede vir die N-COPE subskale het gewissel van goed tot onbevredigend (.73 - .35). Kriterium-verwante geldigheid is bepaal met behulp van korrelasies tussen die N-COPE en ander skale van psigologiese gesondheid.

Hierdie faktore toon groot ooreenkomste, maar ook klaarblyklike verskille van ander coping-skale wat ontwikkel is vanuit Afrika en Asiese perspektiewe. In hierdie studie is bevind dat sekondêre beheer strategieë (die uitoefen van beheer oor ' $n$ situasie deur veranderinge aan die individuele ervaring van situasies, eerder as veranderinge aan die objektiewe werklikheid daarvan, daar te stel), wat in die tradisioneel Westerse beskouing algemeen as oneffektiewe coping-strategieë bestempel word, baie algemeen as coping-strategie in hierdie Afrika-konteks gebruik word. Resultate het 
ook die meer geredelike gebruik van coping-strategieë wat verband hou met kollektiewe ondersteuning, godsdiens en spiritualiteit as coping-strategieë aangedui.

Tekortkominge in die huidige studie is aangedui en voorstelle vir verdere navorsing is gemaak.

Die gevolgtrekking is dat die N-COPE in sy huidige formaat nie volkome geldig vir gebruik in ' $\mathrm{n}$ Afrika-konteks is nie maar dat verdere verfyning van die skaal noodsaaklik is om die belowende moontlikhede daarvan na behore te ontgun. Resultate van die onttrekte faktore van die N-COPE het ' $n$ ander verspreiding gehad as die faktore wat in vorige studies van die S-COPE en die ACSI beskryf is. Om te bepaal of die anderse faktor-verspreiding op ' $n$ unieke patroon van coping-gedrag in hierdie groep Setswana-sprekende Afrikane kan dui, moet verdere studies met die NCOPE in ander gemeenskappe in die Suid-Afrikaanse konteks onderneem word. 


\section{PREFACE}

\subsection{Article format}

For purposes of this mini-dissertation, which is part of the requirements for a professional Master's degree, the article format as described by General Regulation A.13.7 of the North-West University was chosen.

\subsection{Selected journal}

The target journal for publication is the South African Journal of Psychology. The manuscript as well as the reference list has been styled to the journal's specifications, which includes the APA (American Psychological Association) reference style. 


\subsection{LETTER OF CONSENT}

I the co-author(s), hereby give consent that Carelyn van der Walt may submit the manuscript for the purposes of a mini-dissertation. It may also be submitted to the South African Journal of Psychology for publication.

Dr. J.C. Potgieter

Supervisor
Prof. M.P. Wissing

Co-supervisor

Dr. Q.M. Temane

Co-supervisor 


\section{MANUSCRIPT}

\section{Validation of a coping scale in an African context}

C. Van der Walt, J.C. Potgieter, M.P. Wissing, and Q.M. Temane.

School for Psychosocial and Behavioural Sciences, North-West University (Potchefstroom campus), South Africa.

The financial assistance of the National Research Foundation (NRF) towards this research is hereby acknowledged. Opinions expressed and conclusions arrived at, are those of the author and are not necessarily to be attributed to the NRF. 


\subsection{Instructions to authors}

\section{SOUTH AFRICAN JOURNAL OF PSYCHOLOGY}

\subsubsection{Submitting a manuscript}

SAJP is a peer-reviewed journal publishing empirical, theoretical and review articles on all aspects of psychology. Articles may focus on South African, African or international issues. Manuscripts to be considered for publication should be e-mailed to sajp@,unisa.ac.za. Include a covering letter with your postal address, email address, and phone number. The covering letter should indicate that the manuscript has not been published elsewhere and is not under consideration for publication in another journal. An acknowledgement of receipt will be e-mailed to the author within a few days and the manuscript will be sent for review by three independent reviewers. Incorrectly structured or formatted manuscripts will not be accepted into the review process.

\subsubsection{Manuscript structure}

- The manuscript should be no longer than 30 pages and no shorter than 10 pages.

- First page: The full title of the manuscript, the name(s) of the author(s) together with their affiliations, and the name, address, and e-mail address of the author to whom correspondence should be sent.

- Second page: The abstract, formatted as a single paragraph, and no longer than 300 words. A list of at least six key words should be provided below the abstract, with semi-colons between words.

- Subsequent pages: The text of the article. The introduction to the article does not require a heading.

- Concluding pages: A reference list, followed by tables and figures (if any). Each table or figure should be on a separate page. Tables and figures should be numbered consecutively and their appropriate positions in the text indicated. Each table or figure should be provided with a title (e.g., Figure 1. Frequency distribution of critical incidents). The title should be placed at the top for tables and at the bottom for figures. 


\subsubsection{Manuscript format}

- The manuscript should be an MS Word document in 12-point Times Roman font with 1.5 line spacing. There should be no font changes, margin changes, hanging indents, or other unnecessarily complex formatting codes.

- American Psychological Association (APA) style guidelines and referencing format should be adhered to.

- Headings should start at the left margin, and should not be numbered. All headings should be in bold. Main headings should be in CAPITAL LETTERS.

- A line should be left open between paragraphs. The first line of a paragraph should not be indented.

- Use indents only for block quotes.

- In the reference list, a line should be left open above each reference. Do not use indents or hanging indents in the reference list.

\subsubsection{Language and punctuation}

Manuscripts should be written in English. As the SAJP does not employ a full-time or dedicated language editor, authors are requested to send their manuscripts to an external language specialist for language editing before submission. 
6.2. Manuscript title, authors and addresses 


\section{THE VALIDATION OF A COPING SCALE IN AN AFRICAN CONTEXT}

Authors and addresses

Carelyn van der Walt, Johan C. Potgieter, Marié P. Wissing and Michael Q. Temane

School for Psychosocial and Behavioural Sciences, North-West University (Potchefstroom Campus), South Africa.

Johan C. Potgieter *

Department of Psychology

School for Psychosocial and Behavioural Sciences

North-West University, Potchefstroom Campus

Private Bag X6001

Potchefstroom

2520

South Africa

E-mail: johan.potgieter@nwu.ac.za

* To whom correspondence should be addressed. 


\section{Abstract \\ THE VALIDATION OF A COPING SCALE IN AN AFRICAN CONTEXT}

Key words: African context; coping; psychological well-being; psychometric properties; validation, ACSI, N-COPE, S-COPE.

The research aims were to compile and validate a multi-dimensional coping measure, taking African-centred coping behaviour into consideration. In a pilot study the SCOPE (Stapelberg, 1999) and the ACSI (Utsey, Adams \& Bolden, 2000) were administered to Setswana-speaking participants $(N=274)$. The S-COPE served as a measure representative of a traditional dichotomous view of clusters of coping strategies as either Problem- or Emotion-focused. The ACSI (Utsey, Adams, \& Bolden, 2000) was administered as it entails coping strategies developed from an African-centred view of coping. Based on the results from the pilot study, selected items from these measures were combined into a single 35 -item measure, the $\mathrm{N}$ COPE. For purposes of validation, the N-COPE, together with a number of measures of psychological well-being were administered to another group of participants from the same community $(N=1050)$. Reliability coefficients yielded a Cronbach alpha of .74 for the N-COPE total, merely indicating that the measure is indicative of coping behaviour. Results from an exploratory factor analysis showed six factors in the 35item N-COPE: (1) Active problem solving with help from others (2) Spiritual and cultural rituals for solving the problem, (3) Participation in religious activities, (4) Acceptance (5) Denial, and (6) Escape in social activities. Reliabilities for these subscales ranged between .73 and .35 . Criterion-related validity was determined by correlating the N-COPE with other measures of psychological well-being. The extracted factors were largely similar to factors from relevant African and Asian studies on coping, but also revealed various differences. Limitations of the study and suggestions for future research were discussed. It could be concluded that the NCOPE showed promising results for use in this context, but further refinement and validation is necessary. 


\section{THE VALIDATION OF A COPING SCALE IN AN AFRICAN CONTEXT}

Studies by Du Toit (1999), Stapelberg (1999), and Van Eeden (1996) indicate that the successful implementation of coping strategies can serve as a buffer against the individual experience of stress across populations. These findings suggest a positive influence that coping can have on psychological and physical well-being. Research by Ben-Zur (1999) supports the contention that the ways in which people cope with the stresses of daily living affect their psychological, physical and social well-being. Many studies on coping have been conducted (Law, 2004; Stapelberg, 1999; Moos, 1994; Hobfoll et al., 1994; Carver et al., 1989; Kleinke, 1990; and Amirkhan, 1990/1994). Despite the extensive study of the relationship between coping and other aspects of human functioning, and the subsequent development of various coping models, little has been done to identify the variations in coping among different cultural groups (Utsey, Adams, \& Bolden, 2000). This study aims to address this gap by compiling a multi-dimensional coping measure and determining its validity in an African context ${ }^{1}$.

It is contended that improved understanding of possible intercultural differences regarding the utilization and effectiveness of different coping strategies could be to the benefit of the various South African cultural groupings that are currently facing multiple challenges.

Africans today, are exposed to a variety of stressors such as the pervasive effects of Apartheid and racism (Murray, 2002); poverty (Barbarin, 2003); HIV-AIDS; and rapid urbanization (Vorster et al., 2000). The increase in suicidal behaviour of Africans reported by De Bruin (1999) can be viewed as an indicator of poor psychological well-being, possibly due to stress and the lack of appropriate coping skills. In order to improve psychological well-being in the African population, an understanding of the possible variations of coping in an African context is necessary. Chang (1996) pointed out that the process of coping and the choice of coping

\footnotetext{
${ }^{1}$ Note: Any use of the term "African(s) \&/ context" during the course of this manuscript is made as reference to the South African group of Setswana-speaking Africans who participated in this research.
} 
strategies are greatly influenced by cultural factors. Therefore, it is opportune to consider the question whether the theories and coping inventories developed for Western cultures are readily applicable to an African context.

To consider the applicability of measures designed for Western contexts in an African context, it first needs to be determined whether cross-cultural differences in coping exist at all. Research focusing on cross-cultural differences in coping has been initiated by researchers such as O'Connor and Shimizu (2002), who identified differences between the coping styles of British and Japanese respondents. They concluded that the assumed relationships between personal control, stress and psychological well-being as indicated in recent research, may be strongly influenced by an existing Western bias. Results from their study indicated that Japanese respondents showed a coping style focusing significantly less on personal control, and an inclination to the greater use of Emotion-focused coping strategies than their British counterparts. Similar differences were detected by Heppner et al. (2006), who developed the Collectivist Coping Styles (CCS) inventory for an Asian context. The results of that study demonstrated the Asian use of a pattern of coping strategies different from those typically found to be valid in coping inventories designed from a Western perspective. It can be concluded that research has shown that differences do exist between the coping patterns of Western and Asian societies.

As differences between the coping patterns of traditionally Western and Asian cultures clearly exist (Heppner et al., 2006), the question of possible differences in coping patterns between Western and African populations arises. The development of the Africultural Coping Systems Inventory (ACSI) (Utsey, Adams, \& Bolden, 2000) from an African-centred conceptual perspective was aimed at the measurement of possible culture-specific coping strategies used by African Americans. A coping pattern in African Americans differing from traditional Western coping patterns was once again found. The possibility of generalising these findings to an African context now presents itself for consideration.

Due to environmental, geophysical, economical and socio-political differences between African Americans and Africans, the ACSI (Utsey, Adams, \& Bolden, 2000) can also not be presumed to be valid in an African context. Daly et al. (1995) do stress 
the occurrence of coping in a cultural context, and research by Akbar (1996), Ani (1990) and Nobles (1990) indicate the prevalence of an African worldview in the value/belief system of contemporary African Americans. When these two factors are taken into account, the possibility does exist that a greater focus on coping strategies included in the ACSI (e.g. the use of Rituals, Spirituality, Cognitive-emotional debriefing and Collectivistic coping) could be indicative of a coping structure that might be applicable in an African context.

Research addressing the possibility of a unique pattern of coping in an African context, has been initiated by Stapelberg (1999). The COPE (Carver et al., 1989) and the Strategic Approach to Coping Scale (SACS) (Hobfoll et al., 1994) were adapted, translated into Setswana and administered to 738 South African individuals. The obtained reliability and validity indices were satisfactory. However, as Utsey et al. (2000) states, both these measures are based on an ethnocentric European worldview and conceptual framework, focusing on the dichotomous view of coping strategies as either Problem- or Emotion-focused. These measures (the SACS and the COPE) do not represent the full spectrum of coping, including the possibly unique coping strategies characteristic of an African conceptual framework (Utsey et al., 2000), included in the ACSI. Apparently there still is great need for the validation of a coping scale in an African context, acknowledging the possibly unique coping strategies employed by Africans. Once these unique coping strategies have been illuminated, suitable interventions to improve the psychological well-being of South Africans can be employed.

In order to address this need for a coping measure covering a broader spectrum of the possible variations in coping in an African context, this study explored the possibility of designing a multi-dimensional coping measure, combining the dichotomous view of coping strategies (Folkman \& Lazarus, 1980) as being either Problem- or Emotionfocused, with the African-centred approach to coping strategies (Utsey et al., 2000).

Therefore, the aim of this study was to compile a multi-dimensional coping measure, and to determine its validity in an African context. 


\section{METHOD}

\section{Design}

A cross-sectional survey design was implemented in the pilot and the main study.

The results from the pilot study, the first phase of data collection, were used to select items from the ACSI and the S-COPE for inclusion in a single, multi-dimensional measure of coping, called the N-COPE.

In the main study the N-COPE was administered to a different group of Setswanaspeaking participants from the same areas in the North-West Province of South Africa.

\section{Participants}

Selected participants for this study formed part of the larger South African leg of the PURE (Prospective Urban and Rural Epidemiology) project conducted internationally in 16 countries over a period of 12 years. During 2005, a random selection of 6000 households was made in both urban and rural areas in the North-West province, South Africa. Based on an availability sample, 2000 participants from these households were selected for participation in the current study.

In the pilot study 274 participants from the Ikageng, Ganyesa and Tlakgameng communities were selected for the completion of the S-COPE (Stapelberg, 1999) and the ACSI (Utsey et al., 2000).

In the main study, 1050 participants were selected for the validation process, amounting to a total of 1334 participants for both phases of the study. The demographic particulars for the second phase were as follows: There were 444 participants from Ikageng, divided as 229 participants representing a formal urban Setswana-speaking community and 214 participants representing an informal urban Setswana-speaking community. In Ganyesa 280 participants representing a semi-rural Setswana-speaking community were selected and 317 participants from Tlakgameng were selected to represent a deep rural Setswana-speaking community. The group of participants consisted of 392 men and 648 women with ages ranging between 32 and 
87 years. All participants voluntarily took part in the study and provided informed consent, thereby enabling the use of information obtained from them for research purposes.

\section{Measures}

\section{Measures used in the pilot study}

The S-COPE (Stapelberg, 1999).

In the study by Stapelberg (1999) the original version of the COPE (Carver et al., 1989) was translated into Setswana and named the S-COPE. Some items were slightly altered to improve relevance in a South African context. The COPE is a measure focused on the dichotomous view of clusters of coping strategies and consists of 53 items, using a seven point Likert-type measure for responses. In the S-COPE three subscales emerged, namely: 1. Problem-focused coping strategies, 2. Emotionfocused coping, and 3. Less useful strategies. Satisfactory reliability and validity results were indicated, with Cronbach alpha reliability indices varying between .58 and .85 for the total group (Stapelberg, 1999). Motivation for the use of the S-COPE was based on the fact that the S-COPE is an example of a measure constructed according to the dichotomous view of clusters of coping strategies. Therefore, the SCOPE was administered in the pilot study with the view that items from it would be included in the compilation of the N-COPE. The initial selection of the S-COPE was further based on the satisfactory reliability and validity indices previously obtained in a Setswana community as reported by Stapelberg (1999). Criteria for item selection will be discussed in the Procedure section.

The ACSI (Utsey, Adam, \& Bolden, 2000).

Motivation for the inclusion of the ACSI (Africultural Coping Systems Inventory) in the pilot study was based on its representation of the focus on an African-centred application of various culture-specific strategies in coping behaviour. The use of the ACSI was further based on the assumption, as previously indicated, that the specific coping strategies identified within African American culture (Utsey et al., 2000) might be generalised to a South African community based on shared cultural roots. The ACSI is a 42-item self-report measure. Utsey et al. (2000) indicated four significant factors, namely: Cognitive/emotional debriefing consisting of 11 items, Spiritual-centred coping consisting of 8 items, Collective coping consisting of 8 
items, and Ritual-centred coping consisting of 3 items. Cronbach alpha reliability indices between .71 and .80 were found (Utsey et al., 2000).

\section{Measures used in the main study}

\section{The N-COPE}

The compilation of the N-COPE was based on the selection of items from both the SCOPE and the ACSI and compiling it into a single multi-dimensional measure. The selection of items from the S-COPE and the ACSI were based on results from the pilot study. Permission to adapt and combine the measures had been obtained from the authors and two items formulated by the authors were added (items 34 and 35). Additional information regarding the N-COPE is supplied in the Procedure section.

The following questionnaires were also included in the main study in order to establish the criterion-related validity of the N-COPE:

The Sense of Coherence scale (SOC) (Antonovsky, 1993).

The Sense of Coherence Scale (SOC) is a 29-item scale measuring personal sense of coherence, which is concerned with the way individuals experience the world and their life in it. The construct has three dimensions, namely: Meaningfulness, Manageability and Comprehensibility. Viewed as an important determinant of psychological well-being, sense of coherence has been positively correlated with both psychological and physical well-being (Antonovsky, 1987; Wissing \& Van Eeden, 2002). In 26 studies the SOC displayed good content validity, criterion-related validity, internal reliability coefficients of .78 to .93 , as well as test-retest reliability indices between .56 and .96 (Antonovsky, 1993). Reliability and validity for use in an African group had been indicated by Wissing et al. (1999).

\section{The Affectometer 2 (Short version) (AFM2) (Kammann \& Flett, 1983).}

The AFM2 was developed to measure a sense of general well-being and happiness. By determining the balance between positive and negative affect, psychological wellbeing is measured on an affective level (Kammann \& Flett, 1983). Two sub-scales, Positive affect and Negative affect, each consisting of 10 items, constitute the AFM2. Positive-negative affect balance (PNB) is indicated by determining the ratio between Positive and Negative affect scores. The extent of well-being experienced is presented 
by the predomination of Positive affect over Negative affect (Kammann \& Flett, 1983). Cronbach alpha reliability indices of .88 to .93 were indicated by Kammann and Flett (1983). The applicability of the scale in a South African context was attested to in an article by Wissing et al. (1999).

The Satisfaction with Life Scale (SWLS) (Diener et al., 1985).

This five-item scale was developed to indicate individual satisfaction with life. An evaluation of quality of life, as indicated by personal criteria, is measured on a cognitive-judgmental level. A two-month test-retest reliability index of .82 and a Cronbach alpha reliability index of .87 have been reported for this instrument (Diener et al., 1985). The SWLS was found to be valid and reliable to be used in a South African context (Wissing et al., 1999).

The General Health Questionnaire (GHQ) (Goldberg \& Hillier, 1979).

The GHQ was developed to detect common symptoms that are indicative of the various syndromes of mental disorder. The following sub-scales exist: Somatic Symptoms, Anxiety and Insomnia, Social Dysfunction and Severe Depression. Goldberg et al. (1997) reported Cronbach alpha reliabilities between .82 and .86 for the different sub-scales. In a South African sample, Cronbach alpha reliability indices between .77 to .84 for the sub-scales and .91 for the total score were established (Wissing \& Van Eeden, 2002). In 1999 Wissing et al. reported acceptable reliability and validity indices for use in a Setswana-speaking group.

\section{Procedure}

This study is a crosscutter between the PURE-SA (Prospective Urban and Rural Epidemiology - South Africa) and FORT2 (Fortology: Understanding and promoting psychosocial health, resilience and strengths in an African context) projects, conducted within AUTHeR (Africa Unit for Transdisciplinary Health Research).

In the pilot study, two existing coping measures (the S-COPE and ACSI) were administered to a group of 274 Setswana-speaking African participants. Based on descriptive statistics of results from the pilot study, items from the ACSI and the SCOPE were selected for inclusion in a new multi-dimensional measure of coping within the African context, called the N-COPE. Three item characteristics were taken 
into consideration for the exclusion of items, namely: the items with standard deviations greater than 0.25 from the mean, item correlations with the sub-test total with values lower than .20 , as well as final communality estimates lower than .50 . Item selection was further refined during a focus group discussion where the cultural applicability of individual items was discussed. Two items aimed at the use of rituals as coping strategy were formulated and added by the authors. Based on these procedures, a total of 35 items were used in the N-COPE. A four-point Likert-type design for responses was used and was phrased in the following manner: $1=I$ usually don't do this at all, 2 = I usually do this a little bit, $3=I$ usually do this a medium amount, and $4=$ I usually do this a lot.

Training was provided to the16 Setswana-speaking fieldworkers who took part in the administration of the above-mentioned measures to selected participants in the Ikageng, Tlakgameng and Ganyesa communities. Training consisted firstly of a discussion about the basic principles of survey research, the administration of the battery of measures and the manner in which data should be gathered. Secondly, students in Psychology administered the battery of measures to each fieldworker. This was followed by an open discussion where fieldworkers indicated problematic items and administrative procedures. The meaning of each translated item was compared to the English version in order to ensure accurate translation. With certainty of the fieldworkers' understanding of each item, fieldworkers had to administer the measures to each other, to ensure that every fieldworker would get the opportunity to receive feedback on their interview skills. As most participants from the deep rural areas are illiterate, a structured interview format was used during administration.

The N-COPE, as all other measures employed in this study, was translated into Setswana by a registered African translator, back translated by two multi-lingual African doctoral students, and finalised using a research committee approach (Van der Vijver \& Leung, 1997).

In the main study, the N-COPE was administered with the other measures of psychological well-being, to 1050 participants from the same communities used in the pilot study. 


\section{Data analysis}

Descriptive statistics such as means and standard deviations, as well as reliability coefficients such as Cronbach alphas, inter-item and item-total correlations were computed with SPSS and Statistica. These reliability indices provide an indication of the homogeneity and consistency of the scale items and responses (Smit, 1991). As only selected items from both the ACSI and the S-COPE were used in the compilation of the N-COPE, complete sub-scales from these original measures are not represented in the N-COPE. Therefore, confirmatory factor analysis, which would be the first step in a validation process, was not applicable. An exploratory factor analysis was conducted to determine the factor pattern. Criterion-related validity was determined by correlating the results of the N-COPE with a number of psychological well-being measures (e.g. SOC, AFM, SWLS and GHQ).

\section{Ethical considerations}

The personal information of participants was treated confidentially and informed consent was obtained from all participants prior to their participation. A registered psychologist was available throughout the period of data collection should such services be required. The Ethics Committee of the North-West University provided ethical approval for the PURE project (approval number 04M10), and for the FORT2 project (approval number 05K10).

\section{RESULTS}

\section{Descriptive statistics and reliability indices for the N-COPE}

Descriptive statistics and reliability indices of the N-COPE total are reported in Table 1. The highest item means yielded values above 3.00 (items 1,12 and 32) while the lowest item means were below 2.00 (items 24 and 34), with the majority of the item means ranging between values of 2.00 and 3.00. Standard deviations ranged between 0.87 and 1.14. The kurtosis indicated that the largest deviations from zero were greater than 1.30, and all deviations, excluding one item, were negatively skewed, indicating a relatively normal distribution in the data.

The Cronbach alpha reliability coefficient for the total N-COPE was .74, merely indicating that the N-COPE is a measure indicative of coping behaviour. Nunnally and Bernstein (1994) reported that a modest reliability of .70 could be regarded as 
sufficient during the early stages of scale validation. The Cronbach alpha indices for the sub-scales (.73 for APO and SCR to .35 for PRA) (see Table 3) are lower than coefficients reported for the S-COPE (Stapelberg, 1999) and the ACSI (Utsey et al., 2000). Due to the unsatisfactory nature of the Cronbach alpha coefficients for the subscales and the indication of poor reliability in the measure it provides, no further report of the descriptive statistics for the N-COPE sub-scales will be provided in this manuscript. Except for the already reported coefficients for the N-COPE sub-scales, only descriptive statistics for the N-COPE total will be reported and discussed hereafter.

Mean inter-item correlations which serve as a straightforward indicator of internal consistency (Clark \& Watson, 1995), yielded values ranging from .05 to .16 with the majority of correlations above .10 . With only a few items yielding values that fall within the desirable range for mean inter-item correlations indicated by Clark and Watson (1995) as values between .15 and .50 , it can be concluded that the internal consistency is not satisfactory in all respects. Possible explanations for these lower overall inter-item correlations will be provided during the discussion. The same guidelines as indicated for the interpretation of mean inter-item correlations can be used for the interpretation of item-total correlations, namely optimally ranging between .15 and .50 (Clark \& Watson, 1995). With item-total correlations ranging between .06 and .45 in the current results, some homogeneity clearly exists in the measure, despite the unsatisfactory inter-item correlations and coefficients obtained.

[Table 1]

\section{Factor analysis}

An exploratory factor analysis using the maximum likelihood method of factor extraction with oblique rotation was conducted on the N-COPE. Results are reported in Table 2. Due to missing values, 156 cases were excluded. A large number of participants $(n=894)$ were however still involved with this analysis of the 35 -item scale, which yielded a subject-item ratio greater than 20:1. The Kaiser-Meyer-Olkin measure of sampling adequacy yielded a value of 0.8 , which is in accordance with the criteria set by Tabachnick and Fidell (2001). 
Using the principal components method of factor extraction, eleven factors with eigen values greater than 1.00 were extracted with the Kaiser-Guttman criterion, explaining $55.96 \%$ of the variance. Velicer and Jackson (1990) indicated, however, that this method of determining the number of factors to retain is one of the least accurate, as it often yields too many factors. A scree test (Zwick \& Velicer, 1982) was therefore used, which yielded six factors, explaining $39.34 \%$ of the variance.

As maximum likelihood is the preferred method of factor extraction when data is relatively normally distributed (Fabrigar, Wegener, MacCullum, \& Strahan, 1999) and utilization of this method yielded the same six-factor model for the data, it was selected as extraction method in this study. The Goodness-of-fit Test conducted with the maximum likelihood method of factor abstraction yielded a Chi-square of 1191.517 , the lowest value yielded by all available extraction methods ( $d f=400$ and Sig. $=0.000$ ), for the six-factor model. The Bartlett's Test of Sphericity supported the factorability of the data with an approximate Chi-square of $5420.871(n=894, d f=$ 595 and $p<.0001$ ), indicating a relatively normal distribution of the data. An oblique oblimin rotation was used, as Church and Burke (1994) illustrated that the use of orthogonal methods may not be suitable for measures of constructs and oblique rotation allows for some correlation between factors (Floyd \& Widaman, 1995). Although the rotation output is slightly more complex than with orthogonal methods, a theoretically more accurate and more reproducible solution is usually obtained (Costello \& Osborne, 2005). After rotation the six-factor model was judged as the best fit for the data, as it resulted in the "cleanest" factor structure with the least crossloadings, the most items loading above .30 and no factors with fewer than three items (Costello \& Osborne, 2005).

The six factors extracted are as follows: (1) Active problem solving with help from others (APO) consists of eleven items and accounts for $11.56 \%$ of the explained variance $(\alpha=.73)$. (2) Spiritual and cultural rituals for solving the problem (SCR) consists of seven items and accounts for $9.29 \%$ of the explained variance $(\alpha=.73)$. (3) Participation in religious activities (PRA) consists of three items and accounts for $5.24 \%$ of the explained variance $(\alpha=.35)$. (4) Acceptance (ACC) consists of three items and accounts for $4.69 \%$ of the explained variance $(\alpha=.55)$. (5) Denial (DEN) consists of three items and accounts for $4.51 \%$ of the explained variance $(\alpha=.42)$. (6) 
Escape in social activities (ESA) consists of three items and accounts for $4.05 \%$ of the explained variance, all together totalling $39.34 \%$ of variance explained ( $\alpha=.44$ ). Elaboration on the content of this established six-factor model will follow in the discussion.

Communalities for all items were generally low, varying between values of .07 and .50. According to Costello and Osborne (2005), low to moderate communalities (.40 to .70) can be expected in the social sciences and can either indicate that items are not related, or that additional factors should be explored. The Goodness-of fit Test indicated the six-factor model as best fit for the data, which indicates a minimal likelihood of the existence of additional factors that should be explored. Most of the indicated factors have only the minimum suggested number of three items per factor and therefore cannot be seen as strong factors (Costello \& Osborne, 2005). Hence, more items with similar content might be included for future research in order to create stronger factors, greater cohesion between individual items and improved communalities.

Items $6,17,25,26,27$ and 33 did not load significantly on any of the extracted factors. When the quantitative results are examined in totality, it is clear that items 6 , 25,26 and 27 all displayed very low mean inter-item correlations, low correlations with the total and low communalities. Item 17 also displayed low inter-item correlations, but surprisingly had satisfactory correlations with the total and acceptable communality estimates. Item 33 displayed very low inter-item and itemtotal correlations, but acceptable communality estimates. The poor internal consistency of these items can be ascribed to various factors. When the content of these items are reviewed, it is apparent that some of these items clearly do not fit with any of the indicated factors. Unclear formulations, the lack of applicability of certain items in the socio-economic context of the participants, and the discrepancy between the illiteracy of participants and the level of vocabulary used in some items may also have negatively influenced participant responses. As a result, items 6, 17, 25, 26, 27 and 33 , should probably be carefully reformulated or replaced by other items in the further refinement of the N-COPE.

[Table 2] 


\section{Criterion-related validity of the $\mathrm{N}-\mathrm{COPE}$}

Criterion-related validity was determined with the calculation of Pearson product moment correlations between the N-COPE, its indicated factor groupings and a number of measures of psychological well-being (AFM2, SWLS, SOC and GHQ). Results are reported in Table 3. Yielded correlations between the N-COPE and other measures of psychological well-being were generally low, although several of the correlations proved to be statistically significant. The highest correlations were found between the N-COPE (Total) and the SWLS, and the N-COPE (APO) and the AFM2PNB with a value of .21 in both cases. The lowest correlations of .01 were displayed between both the N-COPE (Total) and the N-COPE (PRA), and the GHQ.

Statistically significant correlations were indicated for the N-COPE (APO), N-COPE (SCR) and N-COPE (ACC), with all the other measures of psychological well-being. N-COPE (APO) and N-COPE (SCR) also yielded satisfactory Cronbach alpha coefficients. The higher correlation and statistical significance between the N-COPE (APO) and the other measures of psychological well-being confirms the importance of a collectivistic element in effective coping strategies in this African context.

[Table 3]

\section{DISCUSSION}

The aim of this study was to compile a multi-dimensional coping scale and determine its validity in an African context. The N-COPE was compiled with the aim to provide such a multi-dimensional measure including both a traditional Western view of clusters of coping strategies as Problem- or Emotion-focused, and an African-centred view with focus on typical African coping strategies.

Descriptive statistics indicated item means predominantly ranging between 2 and 3 . This might be the result of the four point Likert-type design of the measure, as individuals might be more prone to answer "I usually do this a little bit" or "I usually do this a medium amount" than to give answers including the terms "a lot" and "don't do this at all". The measure was administered as referring to general coping behaviour in stressful situations and not in a specific, stressful situation. In many cases this could 
also lead to the exclusion of more specific participant responses like "a lot" and "not at all".

Reliability indices showed some variation. The Cronbach alpha for the total N-COPE of .74 can be viewed as adequate, but Cronbach alpha reliability coefficients for the sub-scales varied. This result for the sub-scale coefficients are considerably lower than the Cronbach alphas indicated for the S-COPE (i.e. coefficients between .58 and .85) (Stapelberg, 1999) and the ACSI (Utsey et al., 2000) (i.e. coefficients between .71 and .80 ). Mean inter-item correlations were generally low and not satisfactory, but item-total correlations indicated some homogeneity in the items of the N-COPE. However, the poor reliability coefficients for some sub-scales are problematic as poor reliability compromises any conclusions that might be drawn from the data.

Exploratory factor analysis showed relatively low communalities and yielded the six factors previously reported. The content of the six factors can be described as follows:

Factor 1: Active problem solving with help from others (APO) contains items that reflect an active approach to coping, which involves the goal-directed seeking of assistance, support and advice from a variety of sources in order to solve a problem. It includes a strong element of relational support.

Factor 2: Spiritual and cultural rituals for solving the problem (SCR) displays items that reflect the use of specific spiritual practices and traditional cultural rituals as a means of coping. Relief is found in the performing of these specific rituals or practices that can be viewed as a way of relieving the individual experience of emotional distress while coping with a specific problem.

Factor 3: Participation in religious activities (PRA) is a distinctly different factor from factor 2 and relates to religious activities as a coping strategy. Participation in these religious activities is directed at solving a problem through reliance on religion for support and guidance. Item 16 loaded significantly on this factor (-.33), but due to its stronger loading on factor 2 (.53), it was selected as part of that factor. When the content of item 16 was reviewed, it was clear that this cross-loading was due to its ambiguous formulation, which should be corrected during further refinement of the N-COPE. 
Factor 4: Acceptance (ACC) consists of items that reflect an acceptance of reality and the unchangeable. Rather than the traditional passive acceptance latently viewed as "giving up" or "not even trying to solve a problem", this manner of coping can be viewed as a way of positively adapting one's attitude in order to accept the unchangeable. Item 19 loaded significantly on both factors 1 and 4, without a clear difference in value. As the formulation of the item is particularly unclear, it should be reformulated. If item 19 is eliminated, factor 4 would not be a desirable factor according to the guidelines set by Costello and Osborne (2005) and the factor will either have to be discarded in total, or further items to strengthen it would have to be created. Due to the relatively high loadings of the other two items of the factor (.68 and .53), the latter strategy is suggested for further refinement of the N-COPE.

Factor 5: Denial (DEN) contains items that relate to an attempt to avoid confronting problems and coping with reality. These items convey an underlying experience of shock resulting in an unwillingness to become involved in coping with certain events or problems. Long-term implementation of denial as a coping strategy can have detrimental consequences for health.

Factor 6: Escape in social activities (ESA) consists of items reflecting attempts to temporarily remove oneself from a stress provoking situation or problem by involvement in social events. This social involvement serves as means for temporarily forgetting stress provoking situations or problems, creating an experience of emotional relief. This factor, similar to factor 1 , involves a strong element of the seeking of social support. In this case, however, the strategy is not aimed at seeking advice in order to actively solve a problem, but at finding temporary comfort by involving oneself with group activities.

These factor groupings reveal overlapping elements with the factor groupings Utsey et al. (2000) reported for the ACSI. As items from the ACSI and S-COPE were used to compile the N-COPE, it could be expected that the N-COPE (APO) and N-COPE (ESA) replicates the collective aspect indicated in the ACSI, and the use of N-COPE (SCR) and N-COPE (PRA) in the N-COPE is comparable to the Spiritual-centred and Ritual-centred coping sub-scales of the ACSI. Despite the large amount of overlap between the measures, it was apparent that factor groupings of the N-COPE had slightly different emphases, such as an underlying collectivism in factors 1 and $6, \mathrm{~N}$ COPE (APO) and N-COPE (ESA), rather than a single factor purely focused on social 
support as indicated in the Collective coping factor of the ACSI. These factors indicate a distinction between seeking the help of others in order to solve a problem representing the Problem-focused view of coping, and merely finding comfort in being part of a group that indicates an Emotion-focused attitude towards coping. This dichotomous distinction of coping strategies as being either Problem- or Emotionfocused (Folkman \& Lazarus, 1980) also crystallised in the second factor, N-COPE (SCR). In the N-COPE (SCR), the use of spiritual and cultural rituals is clearly aimed at solving a problem, which represents active problem-solving coping strategies. Different from the two factor division of Spiritual-centred and Ritual-centred coping as reported by Utsey et al. (2000), these aspects of coping were grouped into a single factor named N-COPE (SCR) in this study. A further factor in this study, N-COPE (PRA), stresses the existence of religion as separate from spirituality and the use of rituals in the coping behaviour of Africans. Due to this factor's poor Cronbach alpha coefficient, attempts to improve reliability and determine the factor's true relevance should be made by adding more items focused on religion in further research.

To conclude, it is apparent that elements of both the factors of the ACSI and the SCOPE were still detectable in the results from the current study. Clearly, though, the $\mathrm{N}$-COPE does not exactly replicate coping styles found valid in the S-COPE and the ACSI, but revealed unique elements, suggesting the possibility of a configuration in coping behaviour in an African context that differs from those found to be valid in other contexts. As this study was the first attempt to develop a coping measure, which takes African-centred aspects in a South African context into consideration, no definite conclusions can be drawn from it. Further studies that include the refinement and administration of the N-COPE in other communities will be necessary before the suggested emic pattern of coping in an African context can be either confirmed or discarded.

The factors extracted from the N-COPE also reflect elements of the Collectivist Coping Styles Inventory (CCS) validated in an Asian context (Heppner et al., 2006). It is interesting to note that the six factors extracted from the N-COPE, are represented by almost equivalent sub-scales in the CCS. The CCS is based on the primary and secondary control perspectives to assess problem resolution, as described by Weisz, Rothbaum, and Blackburn (1984). Primary control is present when 
individuals "shape existing physical, social or behaviour realities to fit their perceptions, goals or wishes" (p. 955), while secondary control is described as the exertion of control over the personal psychological impact of stressors through the accommodation and reframing of existing realities without essentially changing them.

Based on the great similarities between the indicated factors of the CCS and the NCOPE, results from this study can also be understood from this framework of primary and secondary control efforts. Factor 1: APO and factor 2: SCR can be viewed as a primary control effort meaning that coping behaviour is directed at taking control of a situation by actively influencing existing realities. Factors 3, 4, 5 and 6 can be viewed as secondary control efforts, meaning that coping behaviour is aimed at accommodating and reframing existing realities in such a way that control over their personal psychological impact is gained without directly attempting to change existing realities.

In a traditional Western approach to coping that is evident in the S-COPE, the focus falls on the difference between Problem-focused and Emotion-focused clusters of coping strategies, which appears to be a view of coping parallel to that found in the CCS. Unlike the view of primary and secondary control efforts, Emotion-focused coping strategies are, however, traditionally viewed as negative, ineffective coping behaviour that leads to learned helplessness and deficits in self-efficacy (Weisz et al., 1984). Therefore, the view of coping from a primary and secondary control framework is preferred, as it acknowledges the potential benefits of secondary control strategies that apparently have great prevalence in an African context. The clear stronger tendency towards the use of different secondary control efforts in this group of Africans and the collectivistic elements in two factors of the N-COPE indicate similarities with, though not a direct replication, of the more collectivistic coping pattern of Asian groups (Heppner et al., 2006). It can be argued that the traditional view that was developed in a Western context, whereby secondary control efforts lead to poor psychological well-being, may not be applicable in the current context.

Despite the poor Cronbach alpha reliabilities obtained for the N-COPE factors, the results from the current study places emphasis on the suggested importance of aspects such as a collectivistic attitude, the importance of spirituality and rituals, as well as 
religion in the coping behaviour of individuals in an African context. This coincides with the African-centred psychological perspective as indicated by Akbar (2004). It can be argued that the initial use of the ACSI, which is based on an African perspective, presupposed the current results towards the affirmation of an African perspective. The S-COPE was however developed from the COPE, which was developed from a Western perspective of human functioning. Therefore, it can be concluded that the assumed existence of an African worldview influencing the values/belief of African Americans and Africans was partly confirmed by the results of this study. This suggests the possibility of a greater ability to generalise results from studies on African Americans for use in some African contexts. As no confirmatory factor analysis was conducted and reliability indices were unsatisfactory, further studies to confirm this finding should be undertaken.

Criterion-related validity as determined by correlating factors extracted from the NCOPE with measures of psychological well-being, yielded variable results. These low and variable correlations, with several correlations indicated as statistically significant, could be explained by a number of possible factors, namely:

1) Four of the six factors extracted have only three items, which would lead to lower correlations.

2) In general, correlations in criterion-related validity are expected to yield lower values than reliability correlations (Roscoe, 1975).

3) The Pearson product moment correlation procedure is based on the underlying assumption of linearity of data, but the N-COPE is slightly negatively skewed, while the other measures of psychological well-being are not, which automatically leads to lower correlations between variables (Anastasi, 1968).

4) According to Anastasi (1986), criterion-related validity gives an indication of a test's accurate prediction of individual behaviour in specified situations, and the nature of the group influences the relationship between the N-COPE and the criterion. Due to the heterogeneity of participants in this study, who can be divided into various groups according to age, strata, or level of literacy, lower predictability of responses is to be expected, leading to lower correlations.

5) The nature of the variables being studied influences the correlations that will be obtained. The N-COPE as a measure of coping behaviour entails a broad construct, which does not measure psychological well-being, but measures a variety of specific 
coping strategies that influence individual psychological well-being. Therefore, a low correlation between the N-COPE, a distinctly different but related variable and the criterion of psychological well-being, was to be expected in the current study.

6) Interpreting the meaning of the size of correlations in any study is dependent on the research problem and correlations found in previous studies (Nunnally, 1975). In this study low correlations were expected when correlation results from previous studies of the S-COPE and the ACSI, from which the N-COPE was compiled, were taken into consideration.

7) Simulated higher statistical significance levels may have been obtained due to the large amount of participants who took part in the study. This implies that the obtained communalities may truly yield even lower values than established in this study.

From results obtained during the criterion-related validity procedure, it can be concluded that the N-COPE is a relatively poor direct indicator of psychological wellbeing, but that the constructs are related. Therefore, the use of psychological wellbeing as criterion in the establishment of criterion-related validity was not the optimal choice for this study and the administration of a measure such as the CCS, which was not available at the time of data collection, should have been preferred for this purpose.

\section{Shortcomings of the current study and suggestions for future research}

In the discussion of the results of the N-COPE, it became apparent that certain weaknesses in the study and the measure exist. These shortcomings indicate the need for future studies focused on the refinement of the measure. The following are some of the weaknesses exposed, and suggestions for future research:

1) In further studies, the group of participants can be divided into two groups and results from factor analysis of the two groups can be compared in an attempt to confirm the suggested emic factor pattern that emerged from the current results.

2) Exploratory factor analysis yielded four of the six factors with only three items. These can be viewed as strong factors, but due to few items and poor factor reliability coefficients, items should be improved in future versions of the N-COPE through adding more items focused on the indicated factor contents.

3) Results indicated that improvement of the N-COPE could be obtained by reviewing the content of certain items. Adjustment to the use of language, the length of items, 
and the cultural applicability of items can be made. Some items, like items 8 and 25 could be reviewed and adjusted to the socio-economic circumstances of subjects, as illiteracy and a lack of electricity in dwellings might have influenced subjects' reactions to these items. Items 26 and 27 may be reviewed for length and complicated vocabulary to try and adjust it for future use in the N-COPE, rather than simply deleting the items.

4) Greater control of the administration of the scale will also probably improve results. Although careful precautions were taken to ensure accurate administration, some error was to be expected. Improvements in the training and controlling of fieldworkers can be effected in future studies.

5) Future studies should also include analyses of the data across different demographic groups with the aim of gaining more specific knowledge of possible intra-group differences that might exist in the group of Setswana-speaking Africans.

6) A further suggestion for future studies is the inclusion of the CCS in its entirety, or partly, in future batteries of measures, on the contention that the great amount of overlap indicated in the factors might be indicative of a greater than expected degree of similarity between Asian and South African patterns in coping behaviour. This measure might be more suitable for the establishment of criterion-related validity than the other measures of psychological well-being used in the current study.

7) Finally, it is suggested that future studies include other cultural groups, for instance Zulu- and Xhosa-speaking participants as an attempt to determine whether the results and suggested unique factor groupings in this study can be generalized to other African cultural groups in South Africa.

\section{CONCLUSION}

The research aims were to create a multi-dimensional measure of coping and determine its validity in an African context. From the results obtained, it can be concluded that the current study succeeded in providing the groundwork for the development of a measure of coping behaviour in an African context. Results showed a six-factor model with some resemblance to the coping strategies employed by African Americans and Asians. Despite the seeming similarity in the coping behaviour of Africans, African Americans and Asians, results also stressed apparent differences in the configuration of the factors of coping behaviour among these groups, indicating a possibly unique pattern of coping in the African context. For this 
suggested emic pattern of coping behaviour to be confirmed, it is required that the indicated configuration of factors be verified with the administration of the N-COPE in other communities in the South African context in further studies. The coping strategies reported for the N-COPE were apparently more focused on relational support, religion, and spirituality than previously thought. Determination of criterionrelated validity showed an existing relationship between the N-COPE and other measures of psychological well-being, but a more suitable criterion should have been used. Though the N-COPE showed adequate results in some respects of this process of initial scale validation, certain weaknesses exist in the current study and further refinement of the N-COPE is necessary. Some shortcomings of the present study were discussed and suggestions for future research were made. Hopefully this information provides a basis for the further exploration of the suggested different configuration of coping behaviour in an African context, and will be utilized towards the aim of improving the psychological well-being of members of the South African population. 


\section{Acknowledgements}

Acknowledgement is hereby provided to the following persons or institutions that contributed to this research process:

- The financial assistance of the National Research Foundation (NRF) towards this research is hereby acknowledged (GUW nr. 2073039). Opinions expressed and conclusions arrived at are not necessarily to be attributed to the NRF.

- Prof. A Kruger who acted as co-ordinator of the PURE-SA project.

- The 16 fieldworkers who gathered the data.

- The research participants who provided the information needed to complete this research.

- This manuscript is based on a mini-dissertation, requirement for a Magister Artium (Clinical Psychology) degree, by the first author under supervision of the co-authors. 


\section{REFERENCES}

Akbar, N. (1996). African metapsychology of human personality. In Azibo, D.A. (Ed.). African psychology: Historical perspectives and related commentary. (pp. 2945). Trenton, NJ: Africa World Press.

Amirkhan, J.H. (1990). A Factor analytically derived measure of coping: The Coping Strategy Indicator. Journal of Personality and Social Psychology, 59, 1066-1074.

Amirkhan, J.H. (1994). Criterion validity of a coping measure. Journal of Personality Assessment, 62(2), 725-733.

Anastasi, A. (1968). Psychological testing. $3^{\text {rd }}$ ed. New York: The Macmillan Company.

Ani, M. (1990). The implications of African American spirituality. In Asante, M.K., \& Asante, K.W. (Eds.). African culture: The rhythms of African unity. (pp. 207-231). Trenton, NJ: Africa World Press.

Antonovsky, A. (1987). Unravelling the mystery of health: How people manage stress and stay well. San Francisco: Jossey-Bass.

Antonovsky, A. (1993). The structure and properties of the sense of coherence scale. Social science medicine, 36(6), 725-733.

Ben-Zur, H. (1999). The effectiveness of coping meta-strategies: Perceived efficiency, emotional correlates and cognitive performance. Personality and Individual Differences, 26, 923-939.

Barbarin, O. (2003). Social risks and child development in South Africa: A nation's programme to protect the human rights of children. American Journal of Orthopsychiatry, 73(3), 248-254. 
Carver, C.S., Scheier, M.F., \& Weintraub, J.K. (1989). Assessing coping strategies: A theoretically based approach. Journal of Personality and Social Psychology, 57(2), 267-283.

Chang, E.C. (1996). Cultural differences in optimism, pessimism, and coping: Predictors of subsequent adjustment in Asian American and Caucasian American college students. Journal of Counselling Psychology, 43(1), 113-123.

Church, A.T., \& Burke, P.J. (1994). Exploratory and confirmatory tests of the Big Five and Tellegen's three- and four-dimensional models. Journal of Personality and Social Psychology, 66, 93-114.

Clark, L.A., \& Watson, D. (1995). Constructing validity: Basic issues in objective scale development. Psychological Assessment, September: 7(3), 309-319.

Costello, A.B., \& Osborne, J.W. (2005). Best practices in exploratory factor analysis: Four recommendations for getting the most from your analysis. Practical Assessment Research and Evaluation, July, 10(7), 1-9.

Daly, A., Jennings, J., Beckett, J.O., \& Leashore, B.R. (1995). Effective coping strategies of African Americans. Social Work, 40, 240-248.

De Bruin, G. (1999). As quoted by Laubscher, L.R. (2003). Suicide in a South African town: A cultural psychological investigation. South African Journal of Psychology, 33(3), 133-143.

Diener, E., Emmons, R.A., Larson, R.J., \& Griffin, S. (1985). The satisfaction with life scale. Journal of Personality Assessment, 49(1), 71-75.

Du Toit, M.M. (1999). Die dinamiek van lewenskonteks, persoonlike faktore, copingprosesse en psigologiese welsyn by jeugdiges, met die oog op programontwikkeling vir kapasiteitsbou. Potchefstroom: PU vir CHO. (Verhandeling voorgelê vir die graad Philosophiae Doctor - Psigologie). 
Fabrigar, L.R., Wegener, D.T., MacCullum, R.C., \& Strahan, E.J. (1999). Evaluating the use of exploratory factor analysis in psychological research. Psychological Methods, 4(3), 272-299.

Floyd, F.J., \& Widaman, K.F. (1995). Factor analysis in the development and refinement of clinical assessment instruments. Psychological Assessment, 7(3), 286299.

Folkman, S., \& Lazarus, R.S. (1980). An analysis of coping in a middle-aged community sample. Journal of Health and Social Behaviour, 21, 219-239.

Goldberg, D.P., \& Hillier, V.F. (1979). A scaled version of the general health questionnaire. Psychological Medicine, 9, 139-145.

Goldberg, D.P., Gater, R., Sartorius, N., Ustun, T.B., Piccinelli, M., Gureje, O., \& Rutter, C. (1997). The validity of two versions of the GHQ in the WHO study of mental illness in general health care. Psychological Medicine, 27, 191-197.

Heppner, P., Heppner, M.J., Wang, Y., \& Wang, L. (2006). Development and validation of a collectivist coping styles inventory. Journal of Counseling Psychology, $53(1), 107-125$

Hobfoll, S.E., Dunahoo, C.L., Ben-Porath, Y., \& Monnier, J. (1994). Gender and coping: The dual-axis model of coping. American Journal of Community Psychology, $22(1), 49-80$.

Kammann, N.R., \& Flett, R. (1983). Affectometer: A scale to measure current level of general happiness. Australian Journal of Psychology, 35(2), 259-265.

Kleinke, C.L. (1990). Coping with life challenges. California: Brooks/Cole Publishing company.

Law, C.A. (2004). Emotional intelligence, sense of coherence and coping behaviour. Vanderbijlpark: North-West University. (Dissertation - M.A. Clinical psychology). 
Moos, R.H. (1994). Conceptual and empirical advances in stress and coping theory. (Paper of lecture delivered at the $23^{\text {rd }}$ international congress of applied psychology, Madrid, Spain, Jul.) Madrid. (Unpublished).

Murray, B. (2002). Psychology tackles apartheid's aftermath. Monitor on Psychology, January, 50-51.

Nobles, W.W. (1990). African philosophy: Foundations of black psychology. In R.E. Jones (Ed.). Black psychology. (pp. 47-63). Berkeley, CA: Cobbs \& Henry.

Nunnally, J.C. (1975). Introduction to statistics for psychology and education. New York: McGraw-Hill Book Company.

Nunnally, J.C., \& Bernstein, I.H. (1994). Psychometric Theory. $3^{\text {rd }}$ ed. New York: McGraw-Hill, INC.

O'Connor, D.B., \& Shimizu, M. (2002). Sense of personal control, stress and coping style: A cross-cultural study. Stress and Health, 18, 173-183.

Roscoe, J.T. (1975). Fundamental research statistics for the behavioural sciences. $2^{\text {nd }}$ ed. New York: Holt, Rinehart and Winston, INC.

Smit, G.J. (1991). Psigometrika. Bloemfontein: HAUM.

Stapelberg, R. (1999). Psigometriese eienskappe van die COPE en SACS by 'n groep Setswana-sprekende Suid-Afrikaners. Potchefstroom: PU vir CHO. (Verhandeling M.A. Kliniese Psigologie).

Tabachnick, B.G., \& Fidell, L.S. (2001). Using multivariate statistics. $4^{\text {th }}$ ed. New York: Harper Collins.

Utsey, S.O., Adams, E.P., \& Bolden, M. (2000). Development and initial validation of the Africultural coping systems inventory. Journal of Black Psychology, 26(2), 194215. 
Van der Vijver, T., \& Leung, K. (1997). Methods and analysis of cross-cultural research. Sage: London

Van Eeden, C. (1996). Psigologiese welstand en koherensiesin. Potchefstroom. (Proefskrif: Ph.D. (psig). - PU vir CHO).

Velicer, W.F., \& Jackson, D.N. (1990). Component analysis versus common factor analysis: Some further observations. Multivariate Behavioural Research, 25(1), 53 59.

Vorster, H.H., Wissing, M.P., Venter, C.S., Kruger, H.S., Kruger, A., Malan, N.T., De Ridder, J.H., Veldman, F.J., Margetts, B.M., \& Macintyre, U. (2000). The impact of urbanization on physical, physiological and mental health of Africans in the North West Province of South Africa: The THUSA study. South African Journal of Science, 96, 505-514.

Weisz, J.R., Rothbaum, F.M., \& Blackburn, T.C. (1984). Standing out and standing in: The psychology of control in America and Japan. American Psychologist, 39, 955969.

Wissing, M.P., Thekiso, S., Stapelberg, R., Van Quickelberge, L., Choabi, P., Moroeng, C., \& Nienaber, A. (1999). The psychometric properties of scales measuring psychological well-being in an African group. (Handout. International Africa psychology congress: Annual congress of the psychological society of South Africa, Durban, July: 18-23, 1999).

Wissing, M.P., \& Van Eeden, C. (2002). Empirical clarification of the nature of psychological well-being. South African Journal of Psychology, 32(1), 32-42.

Zwick, W.R., \& Velicer, W.F. (1982). Factors influencing four rules for determining the number of components to retain. Multivariate Behavioural Research, 17, 253-269. 
Table 2 - Exploratory factor analysis using the maximum likelihood method of factor extraction, with oblimin rotation and Kaiser normalization on items.

\begin{tabular}{|c|c|c|c|c|c|c|c|}
\hline \multirow[t]{2}{*}{ Variable } & \multicolumn{6}{|c|}{ Factor loadings } & \multirow[t]{2}{*}{ Comm. } \\
\hline & 1 & 2 & 3 & 4 & 5 & 6 & \\
\hline N-COPE 22 & .59 & & & & & & .37 \\
\hline N-COPE 20 & .51 & & & & & & .32 \\
\hline N-COPE 12 & .49 & & & & & & .35 \\
\hline N-COPE 30 & .44 & & & & & & .23 \\
\hline N-COPE 32 & .41 & & & & & & .32 \\
\hline N-COPE 19 & .38 & & & .35 & & & .33 \\
\hline N-COPE 7 & .38 & & & & & & .30 \\
\hline N-COPE 28 & .38 & & & & & & .19 \\
\hline N-COPE 4 & .38 & & & & & & .22 \\
\hline N-COPE 14 & .37 & & & & & & .18 \\
\hline N-COPE 3 & .31 & & & & & & .20 \\
\hline N-COPE $17^{*}$ & & & & & & & .31 \\
\hline N-COPE 18 & & .56 & & & & & .38 \\
\hline N-COPE 35 & & .55 & & & & & .34 \\
\hline N-COPE 16 & & .53 & -.33 & & & & .50 \\
\hline N-COPE 23 & & .52 & & & & & .37 \\
\hline N-COPE 24 & & .50 & & & & & .33 \\
\hline N-COPE 10 & & .35 & & & & & .30 \\
\hline N-COPE 34 & & .31 & & & & & .19 \\
\hline N-COPE 33* & & & & & & & .21 \\
\hline N-COPE $6 *$ & & & & & & & .13 \\
\hline N-COPE 5 & & & -.67 & & & & .46 \\
\hline N-COPE 1 & & & -.44 & & & & .40 \\
\hline N-COPE 8 & & & -.31 & & & & .19 \\
\hline N-COPE 25* & & & & & & & .07 \\
\hline N-COPE 21 & & & & .68 & & & .43 \\
\hline N-COPE 31 & & & & .53 & & & .29 \\
\hline N-COPE 27* & & & & & & & .10 \\
\hline N-COPE 2 & & & & & .61 & & .40 \\
\hline N-COPE 9 & & & & & .45 & & .20 \\
\hline N-COPE 29 & & & & & .41 & & .20 \\
\hline N-COPE $26^{*}$ & & & & & & & .07 \\
\hline N-COPE 11 & & & & & & .49 & .24 \\
\hline N-COPE 13 & & & & & & .43 & .25 \\
\hline N-COPE 15 & & & & & & .41 & .20 \\
\hline
\end{tabular}

Note: Values less than 0.3 are not displayed. Items indicated with * did not load significantly on any factors. 
Table 3 - Criterion-related validity: Cronbach alpha reliabilities and Pearson correlation coefficients of the N-COPE with other measures of psychological wellbeing. (Prob. $>/ \mathrm{r} /$ under H0: Rho $=0$ ).

\begin{tabular}{cccccc}
\hline & $\begin{array}{c}\text { Cronbach } \\
\text { alpha } \\
\text { reliability }\end{array}$ & $\begin{array}{c}\text { AFM2 } \\
\text { PNB }\end{array}$ & SWLS & SOC Total & GHQ Total \\
\hline $\begin{array}{c}\text { N-COPE } \\
\text { Total }\end{array}$ & .74 & .09 & .21 & .01 & .08 \\
N-COPE & .73 & .21 & .15 & .16 & -.12 \\
(APO) & & $* * * *$ & $* * * * *$ & $* * * *$ & $* * *$ \\
N-COPE & .73 & -.03 & .18 & -.13 & .19 \\
(SCR) & & $* *$ & $* * * *$ & $* * *$ & $* * * * *$ \\
N-COPE & .35 & .03 & .04 & .08 & .01 \\
(PRA) & & $* *$ & $* *$ & $* *$ & $*$ \\
N-COPE & .55 & .18 & .11 & .10 & -.12 \\
(ACC) & & $* * * *$ & $* * *$ & $* * *$ & $* * *$ \\
N-COPE & .42 & -.06 & .12 & .07 & .07 \\
(DEN) & & $* *$ & $* * *$ & $* *$ & $* *$ \\
N-COPE & .44 & .03 & .17 & -.04 & .03 \\
(ESA) & & $* *$ & $* * * *$ & $* *$ & $* *$
\end{tabular}

Note: N-COPE Total $=$ N-Cope Total; N-COPE (APO) $=$ N-COPE Active problem solving with help from others; $\mathrm{N}-\mathrm{COPE}(\mathrm{SCR})=\mathrm{N}-\mathrm{COPE}$ Spiritual and cultural rituals for solving the problem; N-COPE $(\mathrm{PRA})=\mathrm{N}-\mathrm{COPE}$ Participation in religious activities; N-COPE (ACC) $=$ Acceptance; N-COPE (DEN) $=\mathrm{N}-\mathrm{COPE}$ Denial; N-COPE $(\mathrm{ESA})=$ Escape in Social Activities; AFM2 - PNB $=$ Affectometer $2-$ Positive-negative affect balance; SWLS $=$ Satisfaction with life scale; SOC Total $=$ Sense of coherence scale, Total; GHQ Total $=$ General Health Questionnaire, Total; ${ }^{* * * * *}=\mathrm{p}<0.0001 ; * * * *=p<0.001$; $* * *=\mathrm{p}<0.01 ; * *=\mathrm{p}<0.5 ; *=0.5<\mathrm{p}<1$. 


\section{N-COPE: ENGLISH VERSION}

We are interested in how people respond when they confront difficult or stressful events in their lives. There are lots of ways to try to deal with stress. This questionnaire asks you to indicate what you generally do and feel when you experience stressful events. Obviously, different events bring out somewhat different responses, but think about what you usually do when you are under a lot of stress.

Then respond to each of the following items by telling the field worker which of the response choices listed just below is most true FOR YOU. Please try to respond to each item separately in your mind, and choose your answers thoughtfully. Please answer every item. There are no "right" or "wrong" answers, so choose the most accurate answer for YOU-not what you think most people would say or do. Indicate what YOU usually do when YOU experience a stressful event.
$1=$ I usually don't do this at all
$2=$ I usually do this a little bit
$3=$ I usually do this a medium amount
$4=$ I usually do this a lot

\begin{tabular}{|c|c|c|c|c|}
\hline & $\mathbf{1}$ & 2 & 3 & 4 \\
\hline * 1. Pray that things will work out. & & & & \\
\hline \#2. I refuse to believe it has happened. & & & & \\
\hline $\begin{array}{l}\text { * 3. Get a group of family or friends together to help with the } \\
\text { problem. }\end{array}$ & & & & \\
\hline * 4. Share my feelings with a friend or family member. & & & & \\
\hline $\begin{array}{l}\text { * 5. Go to church (or other religious meeting) to get help } \\
\text { from the group. }\end{array}$ & & & & \\
\hline \# 6. I sleep more than usual. & & & & \\
\hline $\begin{array}{l}\text { * 7. Seek advice about how to handle the situation from an } \\
\text { older person in my family or community. }\end{array}$ & & & & \\
\hline
\end{tabular}




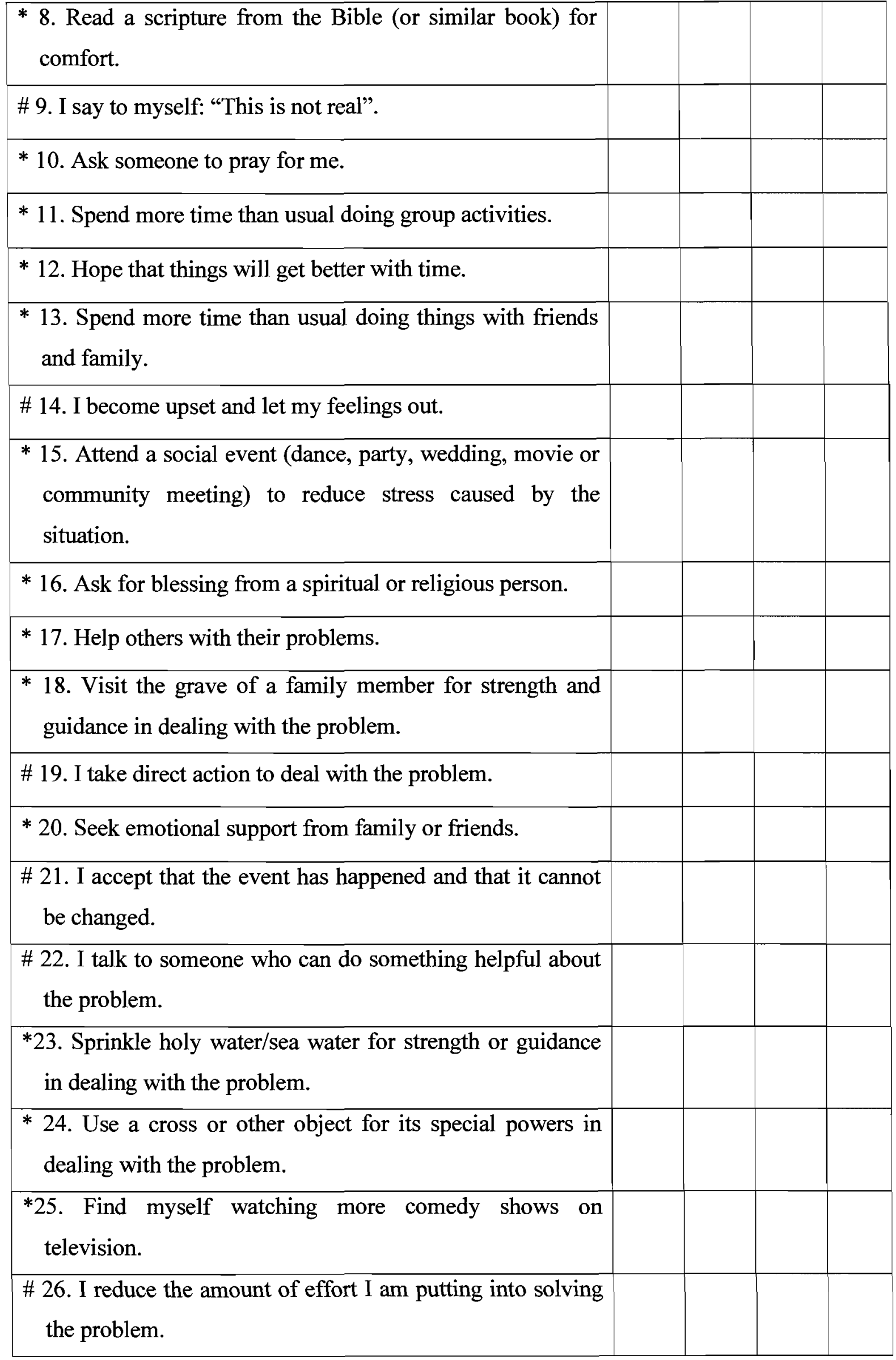




\begin{tabular}{|l|l|l|l|l|}
\hline $\begin{array}{l}\text { \# 27. I feel much emotional distress (upset feelings), and find } \\
\text { myself expressing those feelings a lot. }\end{array}$ & & & & \\
\hline \# 28. I talk to someone to find out more about the situation. & & & & \\
\hline \# 29. I act as though the event has not happened. & & & \\
\hline $\begin{array}{l}\text { \# 30. I concentrate my efforts on doing something about the } \\
\text { problem. }\end{array}$ & & & & \\
\hline $\begin{array}{l}\text { \# 31. I accept the reality of the fact that it happened. } \\
\text { \# 32. I seek God's help. }\end{array}$ & & & & \\
\hline \# 33. I become upset and very aware of my feelings. & & & & \\
\hline + 34. I visit a traditional healer for guidance in handling the \\
event.
\end{tabular}

Note: Items indicated with $\mathbf{a}^{*}$ were derived from the ACSI and items indicated with a \# were derived from the S-COPE. Items marked with a + were added by the authors. 
Correspondence with the authors 


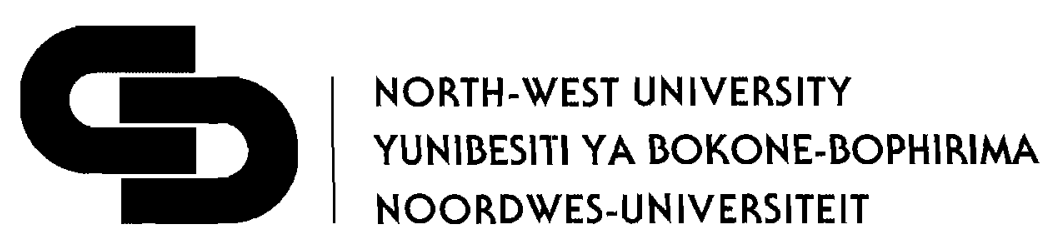

\section{SCHOOL OF PSYCHOSOCIAL BEHAVIOURAL SCIENCES: PSYCHOLOGY}

Tel (018) 018-299-1726

Fax (018) 018-2991730

EMail12520896@puk.ac.za

Professor S.O.Utsey

Virginia Commonwealth University

29 January 2007

College of Humanities and Sciences

Department of Psychology

806 West Franklin Street

Richmond, Virginia

23284-2018

Phone: (804) 828-1144

E-mail: soutsey@vcu.edu

Dear Professor Utsey

Your research on self-regulation, and more specifically coping, is of great interest to me. I am a Masters degree student in Clinical Psychology at the North-West University, Potchefstroom Campus in South Africa. The current focus of research in our department is on positive psychology. As part of the movement to improve the psychological well-being of individuals in South Africa, valid instruments to measure current levels of well-being are necessary. My study, supervised by Dr. J.C. Potgieter and co-supervised by Prof M.P. Wissing and Dr. Q.M. Temane, involves the validation of a coping measure applicable in an African context.

After reviewing qualitative analysis of a study by Pithey (2006, submitted dissertation), the COPE and the ACSI were indicated to be most useful in the validation of a coping scale in an African context. The COPE is viewed as a dichotomous representation of coping as problem-focused of emotion-focused, with subscales focussing on more specific coping strategies that can be divided into the dichotomous structural view. The ACSI was developed specifically with apparent culture-specific coping strategies of African Americans in mind. Africans are presumably more collectivistic, and it can be argued that some of the African collectivism still lingers in employed African American coping strategies. To compile 
a measure that is valid in an African context, it is necessary to take possible culturespecific coping strategies into consideration. The aim of the study is to compile a multidimensional coping measure, and to determine its validity in an African context. The proposed research procedure can be shortly described as follows: firstly, to administer the COPE and the ACSI to a group of Africans in the Northwest province, South Africa. Secondly, to combine strong loading items from the COPE with strong loading items of the ACSI (Africultural Coping Systems Inventory) (Utsey et al., 2000 ), into a single measure, and thirdly, to administer and validate the combined measure in an African context. Both measures will be translated into Setswana (a native language widely used in Southern Africa), and items will be reviewed for translatability and applicability using a research committee approach. Thus, some changes might be made to the content or structure of some items.

I would therefore like to request your permission to use your questionnaire in the compilation of this measure of coping to be validated in an African context in my study.

Your consideration of this matter will be much appreciated.

Kind regards,

Carelyn van der Walt

Intern Psychologist

Email: 12520896@puk.ac.za

Phone: +27 (018) 2991742

PSGJCP C:Imy documentsipersoneel jeplengelse briefhoof jep.doc 
From: $\quad$ Shawn O Utsey/FS/VCU < soutsey@vcu.edu>

To: "Carelyn Van Der Walt" <12520896@nwu.ac.za>

Date: $\quad$ 2007/01/30 04:55:42 PM

Subject: Re: Request

Carelyn,

This sounds like a very interesting and worthwhile study. You may be interested to know that the factor structure of the ACSI was compared across samples of Blacks from West Africa (Ghana), the Caribbean, and the U.S. This study is published in Eductional and Psychological Measurement. I am happy to give you permission to the use the ACSI in your study. However, I would request that, upon completion of your study, you make the ACSI data (i.e., the 30-items specific to the ACSI) for purposes of developing normative data on the instrument. Thanks for your interest in the ACSI. Let me know how I can be of further assistance.

Shawn

Shawn O. Utsey, Ph.D.,

Associate Professor and

Editor, Journal of Black Psychology, Department of Psychology,

(804) 828-1144

(804) 828-2237 


\author{
SCHOOL OF PSYCHOSOCIAL BEHAVIOURAL \\ SCIENCES: PSYCHOLOGY \\ Tel (018) 018-299-1726 \\ Fax (018) 018-2991730 \\ EMail 12520896@puk.ac.za
}

29 January 2007

Department of Psychology

PO BOX 248185

University of Miami

Coral Gables

Florida

33124-0751

USA

Fax: (305) 2843402

Phone: (305) 2842817

Dear Professor Carver

Your research on self-regulation, and more specifically coping, is of great interest to me. I am a Masters degree student in Clinical Psychology at the North-West University, Potchefstroom Campus in South Africa. The current focus of research in our department is on positive psychology. As part of the movement to improve the psychological well-being of individuals in South Africa, valid instruments to measure current levels of well-being are necessary. My study, supervised by Dr. J.C. Potgieter and co-supervised by Prof M.P. Wissing and Dr. Q.M. Temane, involves the validation of a coping measure applicable in an African context.

After reviewing qualitative analysis of a study by Pithey (2006, submitted dissertation), the COPE and the ACSI were indicated to be most useful in the validation of a coping scale in an African context. The COPE is viewed as a dichotomous representation of coping as problem-focused of emotion-focused, with subscales focussing on more specific coping strategies that can be divided into the dichotomous structural view. The ACSI was developed specifically with apparent culture-specific coping strategies of African Americans in mind. Africans are presumably more collectivistic, and it can be argued that some of the African collectivism still lingers in employed African American coping strategies. To compile a measure that is valid in an African context, it is necessary to take possible culture- 
specific coping strategies into consideration. The aim of the study is to compile a multidimensional coping measure, and to determine its validity in an African context. The proposed research procedure can be shortly described as follows: firstly, to administer the COPE and the ACSI to a group of Africans in the Northwest province, South Africa. Secondly, to combine strong loading items from the COPE with strong loading items of the ACSI (Africultural Coping Systems Inventory) (Utsey et al., 2000), into a single measure, and thirdly, to administer and validate the combined measure in an African context. Both measures will be translated into Setswana (a native language widely used in Southern Africa), and items will be reviewed for translatability and applicability using a research committee approach. Thus, some changes might be made to the content or structure of some items.

I would therefore like to request your permission to use your questionnaire in the compilation of this measure of coping to be validated in an African context in my study.

Your consideration of this matter will be much appreciated.

Kind regards,

Carelyn van der Walt

Intern Psychologist

Email: 12520896@puk.ac.za

Phone: +27 (018) 2991742

PSGJICP c:Imy documentslpersoneel jcplengelse briefhoof jcp.doc 
From: $\quad$ "Charles S. Carver" <ccarver@miami.edu>

To: <12520896@puk.ac.za>

Date: 2007/01/30 05:20:09 PM

Subject: $\quad$ Re: SPN Profile Message: Request

I apologize for this automated reply. Information concerning the measure you are asking about can be found at the website below. I think most of your questions will be answered there. If questions remain, however, please do not hesitate to contact me.

Good luck in your work.

http://www.psy.miami.edu/faculty/ccarver/CCscales.html

Permission received when the provided electronic link was followed:

\subsection{Self-Report Measures Available:}

All of these scales are being made available here for use in research and teaching applications. All are available without charge and without any need for permission. Download or print them from the linked pages.

1.6.1 LOT-R (a measure of optimism-pessimism)

1.6.2 COPE (the full version of our measure of coping)

1.6.3 Brief COPE (an abbreviated version of the COPE)

1.6.4 BIS/BAS scales (measures of the sensitivity of incentive and aversive motivational systems)

1.6.5 MAQ (a measure of adult attachment qualities)

1.6.6 MBA (a measure of investment in body image as a source of feelings of selfworth)

1.6.7 ATS (a measure of generalization, overly high standards, and self-criticism)

1.6.8 Benefit Finding (a measure of finding benefit in the experience of having breast cancer)

1.6.9 QLACS: Quality of Life in Adult Cancer Survivors (a new QOL measure for longterm survivors)

1.6.10 MOCS (a measure of targeted and nonspecific effects of an intervention)

$\begin{array}{lllll}\text { 1.6.11 SSSS } & \text { (Sources } & \text { of } & \text { Social } & \text { Support }\end{array}$

1.6.12 WASSUP (Willingly Approach Set of Statistically Unlikely Pursuits)

1.6 .13

1.6.14 Spanish Translations of Brief COPE, LOT-R, MBA, CES-D, and BIS/BAS scales

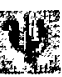

[ Psych Home | Psych Faculty | Carver ] 
